\title{
CO-COMBUSTION OF RICE HUSK AND SINAI COAL IN CIRCULATING FLUIDIZED BED
}

\author{
Hamada M. Abdelmotalib, Mahmoud A. M. Youssef \\ and Ibrahium M El-Mogazy \\ Department of Mechanical Power Engineering and Energy, Faculty of \\ Engineering, Minia University, Egypt
}

(Received May 18, 2011 Accepted July 2, 2011)

\begin{abstract}
Rice husk is one of the most important agricultural residues in Egypt. The present study introduces an experimental investigation on circulating fluidized bed $(C F B)$ combustion of rice husk and co-combustion of rice husk and Egyptian (Sinai) coal. The test rig is a pilot scale CFB combustor of $145 \mathrm{~mm}$ inner diameter, $2 \mathrm{~m}$ tall and $100 \mathrm{~kW}$ thermal capacity. The influences of excess air, and coal share were studied. Temperature and heat flux along the reactor height, in addition to the concentrations of $\mathrm{CO}, \mathrm{NOx}$ and $\mathrm{SO} 2$ in the flue gas out from cyclone were measured. The combustion efficiency was estimated based on $C O$ and unburned char in flue gas. The highest efficiency recorded for rice husk combustion was $98 \%$ at excess air ratio $(E A)=1.1$ and secondary air ratio $(S A R)=50 \%$. Co-combustion of Sinai coal and rice husk reduced CO but increased SO2 and NOx emissions. The results suggest that rice husk is potential fuel that can be utilized for efficient and renewable energy production by using CFB combustion system especially at co-combustion with coal.
\end{abstract}

KEYWORDS: circulating fluidized bed (CFB), rice husk, coal, emissions, combustion efficiency

\section{INTRODUCTION}

Biomass is one of the most important renewable energy resources. With the depletion of oil sources and concerns about global warming, the use of biomass is being considered more frequently [1]. The combustion of residues associated with agricultural production and processing industries in power plants seems to be a promising technique for the future to contribute both reduction of greenhouse gases and solution of the waste disposable problems. Rice husk and straw are the most important agricultural residues in quantity. There are some problems with the rice husk treatment. These problems are due to a great volume of wastes and its local situation. On the other hand, this waste is problematic during its handling and transportation due to low density [2]. Experiments on a cold model showed that rice husk is difficult to be fluidized and adding silicon sand and coal improves the fluidization condition [3]. Burning tests showed that the biomass fuels have the advantage of reaching the diffusion regime at temperatures that can be lower than 727 ${ }^{\circ} \mathrm{C}$, which ensures that the biomass fuels burn in a stable regime [4]. The combustion characteristics of rice husk in a multi-staging vortex combustor at different operating conditions namely; equivalence ratio and secondary air ratio were experimentally studied. The experimental results showed that the maximum temperature was $1176{ }^{\circ} \mathrm{C}$ 
in the vortex chamber. Measurements of gas emissions from cyclone collector consisted of $\mathrm{O}_{2}=2.5 \%, \mathrm{CO}_{2}=17.3 \%$, and $\mathrm{CO}=270 \mathrm{ppm}$ respectively [5]. The optimum fluidizing velocity was investigated during the combustion of rice husk in a benchscale fluidized bed combustor to obtain low carbon ash in the amorphous. The results showed that the optimum fluidizing velocity was approximately 3.3 minimum fluidizing velocity [6].

Through co-firing with rice husk, an effective use of 'as-received' sugar cane bagasse becomes feasible for energy conversion in the fluidized-bed combustion systems [7]. Increased fluidizing velocity adversely affected combustion efficiency while increased coal fraction enhanced combustion efficiency when rice husk co-fired with coal in short-combustion-chamber fluidized-bed combustor [8].

The estimated annual rice production in developing countries is 500 million tones. Approximately 100 million tones of rice husk are available annually for utilization in these countries alone [9]. In Egypt, agriculture wastes are still responsible for environmental problems because many of them are burnt in open fields causing air pollution and without energy recovery [10]. Rice husk, an undesirable agriculture mass residue in Egypt, is a byproduct of the rice milling industry.

The present study investigates the combustion characteristics of rice husk alone and with Egyptian (Sinai) coal. The experiments were carried out on a $100 \mathrm{~kW}$ CFB pilot scale located in the heat laboratory, Faculty of Engineering, Minia University. The study focused on the effects of excess air ratio EA and coal share in the co-combustion on the temperature and heat flux profiles in the CFB combustion, as well as on the major emissions $\left(\mathrm{CO}, \mathrm{NO}_{\mathrm{x}}\right.$ and $\left.\mathrm{SO}_{2}\right)$.

\section{EXPERIMENTAL}

\subsection{Experimental Facilities}

The test rig includes reactor and auxiliary systems; bed recirculation system, air supply, fuel feeding, and exhausts gas suction. An overall schematic of the CFB test rig is shown in Fig. 1. The reactor is an insulated steel cylinder with $145 \mathrm{~mm}$ inner diameter, $2 \mathrm{~m}$ height, and $12 \mathrm{~mm}$ wall thickness. There are two inlets on the reactor to admit secondary air at heights of $0.3 \mathrm{~m}, 0.7 \mathrm{~m}$ above the distributor plate. The bed recirculation system includes connecting pass, cyclone, and return leg. The connecting pass (crosswise parallelepiped canal) connects between the reactor and the cyclone. The cyclone and the return leg complete together the cycle of the circulating solids (sand and unburned solid fuels). The circulating solids are returned to the reactor at $200 \mathrm{~mm}$ above the air distributor through the return leg, which is inclined with $45^{\circ}$. The solid fuel is fed also through this leg where it mixes with the returned solids. Air is used as a career for the fuel and returned solids to the reactor with the aid of gravity. The main air supply is a blower of $15 \mathrm{~kW}$ capacity and $2850 \mathrm{rpm}$. The primary air is admitted to the distributor through a cone vessel of $100 \mathrm{~mm}$ bottom diameter and 140 $\mathrm{mm}$ top diameter. The primary air is preheated by using an electric heater of $4.8 \mathrm{~kW}$ capacity. The distributor has 35 nozzles. Each nozzle is of $10 \mathrm{~mm}$ outer diameter, 5 $\mathrm{mm}$ inner diameter and has four holes of $2.5 \mathrm{~mm}$ diameter on the circumstance. The feeding mechanism of solid fuel is a low speed motor and two pulleys, belt and screw feeder. A gaseous fuel (supplied from four gas bottles) is premixed with the primary air before entering the reactor. A suction fan is used to suck the flue gases to the chimney. 
The temperatures along the reactor were measured by a shielded thermocouple type K. The accuracy of thermocouple was $\pm 2{ }^{\circ} \mathrm{C}$. The analysis of the flue gas is carried out along the reactor and on the gas stream exiting from the cyclone. The concentration of $\mathrm{O}_{2}, \mathrm{CO}, \mathrm{CO}_{2}, \mathrm{SO}_{2}$ and $\mathrm{NO}_{\mathrm{x}}$ were measured by an electrochemical cells analyzer. Then, the measured emissions of $\mathrm{CO}, \mathrm{NO}_{\mathrm{x}}$ and $\mathrm{SO}_{2}$ were recalculated based on $7 \% \mathrm{O}_{2}$ by volume in the flue gas. The accuracy of $\mathrm{O}_{2}$ concentrations and gas emissions measurement was $\pm 1 \%$ and $\pm 4 \%$ respectively. The heat flux to the combustion chamber walls was measured by a plug-type heat flux meter, which has a plug of known thermal conductivity and dimensions. Inside the plug, there are two copper constantan thermocouples, separated by a known distance along the axis of the plug. Hence, the heat flux to the reactor wall can be estimated at every measuring port in $\mathrm{kW} / \mathrm{m}^{2}$. The uncertainty of heat flux value was $\pm 5 \%$. The flow rate of air and gaseous fuel are measured by calibrated orifices. Solid fuel is fed to the furnace at a selected (pre-set) feed rate by the screw conveyor mechanism. Samples of fly ash in flue gas were collected after the suction fan and were analyzed for combustibles.

\subsection{Fuel Characteristics and Bed Material}

As shown in Fig. 2, rice husk has nearly cylindrical shape of $2 \mathrm{~mm}$ diameter and $7 \mathrm{~mm}$ length. It is very light, with packing density of $350 \mathrm{~kg} / \mathrm{m}^{3}$. High volatile content, nearly uniform size and high ash melting points also characterize rice husk. The ash contains $87-98 \%$ silica and small proportion of metallic elements. The proximate and ultimate analysis and other properties of rice husk and Sinai coal are given in Table 1. A commercial gaseous fuel (butagas) is used to start up the combustion process. Butagas is a mixture of $70 \%$ butane and $30 \%$ propane by volume. The bed material is silica sand of $0.543 \mathrm{~mm}$ mean particle diameter and $1414 \mathrm{~kg} / \mathrm{m}^{3}$ bulk density.

Table 1: The properties of rice husk and Sinai coal

\begin{tabular}{|l|c|c|}
\hline & Rice husk [3] & Sinai coal [11] \\
\hline Ultimate analysis: & & \\
\hline $\mathrm{H}_{2} \mathrm{O} \%$ & 6 & 3.8 \\
\hline ash \% & 16.92 & 9.8 \\
\hline $\mathrm{C} \%$ & 37.6 & 67.3 \\
\hline $\mathrm{H} \mathrm{\%}$ & 4.89 & 5.54 \\
\hline $\mathrm{N} \%$ & 1.89 & 0.99 \\
\hline $\mathrm{O} \%$ & 32.61 & 10.26 \\
\hline $\mathrm{S} \%$ & 0.094 & 2.22 \\
\hline Proximate analysis & & 48.9 \\
\hline volatiles \% & 51.98 & 37.5 \\
\hline fixed carbon \% & 25.1 & 3.8 \\
\hline $\mathrm{H}_{2} \mathrm{O} \%$ & 6 & 9.8 \\
\hline ash \% & 16.92 & 9.37 \\
\hline A : F* & 5.3 & 690 \\
\hline Physical properties & & 1600 \\
\hline Bulk density $\mathrm{kg} / \mathrm{m}^{3}$ & 350 & 27976 \\
\hline Real density $\mathrm{kg} / \mathrm{m}^{3}$ & 500 & 0.9 \\
\hline Calorific value $\mathrm{kJ} / \mathrm{kg}$ & 13200 & \\
\hline Mean particle size mm & 2 & \\
\hline
\end{tabular}

* Stoichiometric air to fuel ratio. 


\subsection{Operating Conditions}

This section displays the experimental runs that were carried out using the present CFB test rig. The bed is heated prior to admitting solid fuel by burning a butagas/air mixture. Then solid fuels are introduced into the combustion chamber. The butagas supply is gradually decreased and stopped completely after the combustion is selfsustained. The electric heater is turned on during the start up procedure and stays on during the combustion process of solid fuels. The temperature of primary air is about $110{ }^{\circ} \mathrm{C}$. For the co-combustion tests, the coal was premixed with rice husk in different mixing ratios to obtain coal share of $25 \%, 50 \%$ and $75 \%$ (thermal basis). The mixture of coal and rice husk is fed to the fluidized bed by the screw feeder.

Experiments focused on the effect of excess air ratio and coal share on the combustion characteristics such as temperature, heat flux and gas emission. The excess air ratio is defined as the ratio of actual combustion air to the stoichiometric combustion air. Experiments can be divided into two groups. The first group deals with the combustion of rice husk. The second group deals with the co-combustion of rice husk and Sinai coal. The temperature and heat flux were measured along the reactor. The gas emissions were measured after the cyclone. All operating parameters of rice husk combustion are indicated in Table 2, and of co-combustion in Table 3. The thermal load is the summation of the fuel heating value and the heat input by preheated primary air.

Table 2: General layout of the experimental procedure of rice husk combustion

\begin{tabular}{|l|c|c|c|c|}
\hline \multicolumn{1}{|c|}{ Fuel } & \multicolumn{4}{c|}{ Rice husk } \\
\hline Experiment No. & 1 & 2 & 3 & 4 \\
\hline Fuel feed rate, $\mathrm{kg} / \mathrm{h}$ & \multicolumn{4}{|c|}{25} \\
\hline Excess air ratio & 1.1 & 1.3 & 1.6 & 1.85 \\
\hline Secondary air ratio \% & \multicolumn{5}{|c|}{30} \\
\hline Mass of bed, kg & & 106.2 & 106.6 & 107 \\
\hline Thermal load, $\mathrm{kW}$ & 106 &
\end{tabular}

Table 3: General layout of the experimental procedure of co-combustion of rice husk and Sinai coal

\begin{tabular}{|l|c|c|c|}
\hline \multicolumn{1}{|c|}{ Fuel } & \multicolumn{3}{c|}{ Rice husk and Sinai coal mixture } \\
\hline Experiment .No. & 1 & 2 & 3 \\
\hline $\begin{array}{l}\text { Coal share\% (thermal } \\
\text { basis) }\end{array}$ & 25 & 50 & 75 \\
\hline Coal feed rate, kg/h & 3.5 & 7 & 10 \\
\hline Rice husk feed rate, $\mathrm{kg} / \mathrm{h}$ & 19 & 12.5 & 6 \\
\hline Excess air ratio EA & $1.1-1.3-1.6-1.85$ & $1.1-1.3-1.6-1.85$ & $1.1-1.3-1.6-1.85$ \\
\hline Secondary air ratio \% & \multicolumn{3}{|c|}{50} \\
\hline Mass of bed, kg & \multicolumn{3}{|c|}{3} \\
\hline Thermal load, kW & 106.4 & 106.9 & 107.2 \\
\hline
\end{tabular}


The gas emissions were measured after the cyclone and related to $7 \% \mathrm{O}_{2}$ in flue gas. Based on $\mathrm{CO}$ emission and unburned carbon content in fly ash, the combustion efficiency was calculated for biomass fuels and Sinai coal. The unburned carbon content in fly ash (at chimney) was analyzed and found to be in the range of 1.6 - $3.8 \%$ (by weight). Combustion efficiency $\left(\eta_{c}\right)$ is calculated by the following equation [9]:

$\eta_{\mathrm{c}}=\left[\left(\mathrm{E}_{\mathrm{f}}-\mathrm{E}_{\mathrm{fg}}-\mathrm{E}_{\mathrm{ash}}\right) / \mathrm{E}_{\mathrm{f}}\right] \times 100 \%$

where $E_{\mathrm{f}}$ is the heating value of the fuel, $\mathrm{E}_{\mathrm{ash}}$ is the energy loss as unburned carbon in the fly ash, and $\mathrm{E}_{\mathrm{fg}}$ is the energy loss as carbon monoxide in the flue gas. The calorific values of CO and carbon were taken as $10160 \mathrm{~kJ} / \mathrm{kg}$ and $33829 \mathrm{~kJ} / \mathrm{kg}$ respectively.

\section{RESULTS AND DISCUSSION}

\subsection{Rice Husk Combustion}

\subsubsection{Temperature Distribution and Heat Flux}

Figure 3 describes the effect of excess air ratio on bed temperature at a height above the air distributor of $0.1 \mathrm{~m}$. As expected, increasing excess air ratio results in decreasing bed temperature. The temperature decreases from $960{ }^{\circ} \mathrm{C}$ to $850{ }^{\circ} \mathrm{C}$ when EA increases from 1.1 to 1.85 . The temperature and heat flux distribution along the reactor height for rice husk combustion at $\mathrm{EA}=1.1$ and $\mathrm{SAR}=50 \%$ are represented in Fig. 4. It is observed that both temperature and heat flux decrease with the height above the air distributor due to the heat losses to the reactor walls. The heat flux ranged between 40.27 and $85.23 \mathrm{~kW} / \mathrm{m}^{2}$.

\subsubsection{Gas Emissions}

The effect of excess air ratio on $\mathrm{CO}$ and NOx emissions at $\mathrm{SAR}=50 \%$ for rice husk combustion is plotted in Fig. 5. The figure clarifies that the $\mathrm{CO}$ emission increases with increasing the excess air. This may be attributed to the decrease in temperature occurred by the excess air. The value of $\mathrm{CO}$ emission varies between $0.12 \%$ and $0.38 \%$. It can be concluded that $\mathrm{EA}=1.1$ satisfies the best conditions for lowest values of $\mathrm{CO}$ emission. The figure also illustrates that, the NOx emissions slightly decrease with increasing excess air ratio in contrast to the $\mathrm{CO}$ emission trend. The value of $\mathrm{NOx}$ emission varies between $100 \mathrm{ppm}$ and $110 \mathrm{ppm}$.

Figure 6 describes the variations of $\mathrm{CO}_{2}$ and $\mathrm{O}_{2}$ concentration with change of excess air ratio. From this figure, it is observed that the $\mathrm{CO}_{2}$ concentration decreases with increasing the excess air ratio. This can be explained with the dilution effect of excess air. The values of $\mathrm{CO}_{2}$ concentration varies between $3.6 \%$ and $6.5 \%$. As expected, increasing excess air ratio causes increasing $\mathrm{O}_{2}$ concentration in flue gases. The $\mathrm{O}_{2}$ concentration varies from $16 \%$ to $17.2 \%$.

\subsubsection{Combustion Efficiency}

The effect of excess air ratio on the combustion efficiency of rice husk is shown in Fig.

7. It is noticed that the combustion efficiency decreases with increasing excess air ratio. The combustion efficiency values varied between $94 \%$ and $98 \%$. Table 4 
indicates more details about the heat losses due to incomplete combustion of $\mathrm{CO}$ emission in flue gas and unburned carbon in fly ash.

Table 4 Heat losses and combustion efficiency of rice husk in CFB at different values of excess air.

\begin{tabular}{|c|c|c|c|}
\hline EA & SAR $\%$ & $\begin{array}{c}\text { Unburned carbon } \\
\text { in fly ash \% }\end{array}$ & $\boldsymbol{\eta}_{\mathbf{c} \%}$ \\
\hline 1.1 & \multirow{4}{*}{50} & 1.6 & 98 \\
\hline 1.3 & & 2.5 & 96 \\
\hline 1.6 & & 3.1 & 94.5 \\
\hline 1.85 & & 3.8 & 94 \\
\hline
\end{tabular}

\subsection{Co-combustion of Rice Husk and Sinai Coal}

\subsubsection{Temperature Distribution and Heat Flux}

The results in Fig. 8 clarify the temperatures distribution along the combustion chamber height for the co-firing rice husk and Sinai coal. The temperature was measured at mixing ratios of $25 \%, 50 \%$, and $75 \%$ of thermal load at EA=1.85 where the lowest values of $\mathrm{CO}$ were found. It is observed that the temperature reaches maximum values of $850-960{ }^{\circ} \mathrm{C}$ at bed region and then it gradually decreases along the combustion chamber. It is found also that the temperature level increases with increasing the coal share percentage. This may resulted from the higher adiabatic flame temperature of coal than of rice husk. The maximum temperature of $960^{\circ} \mathrm{C}$ was achieved at $75 \%$ coal share.

The heat flux distribution along the height of combustion chamber for the cocombustion is shown in Fig. 9. It is observed that the heat flux increases with increasing the coal share (as found in temperature distribution in Fig. 8). The maximum value of heat flux is $94.28 \mathrm{~kW} / \mathrm{m}^{2}$ at $0.1 \mathrm{~m}$ above the distributor and coal share of $75 \%$.

\subsubsection{Gas Emissions}

Figure 10a presents the variations of $\mathrm{CO}$ emission with coal share of $0 \%, 25 \%, 50 \%$, and $75 \%$ at $\mathrm{EA}=1.85$ and $\mathrm{SAR}=50 \%$. The obtained results in this figure clarified that the $\mathrm{CO}$ emissions decrease with increasing coal share. This may be due to increasing bed temperature and in turn increasing burning rate of fuel. Also, this may be explained with the higher density of coal particle in comparison with rice husk. In turn, the residence time of coal particle is longer than it of rice husk. Also, the higher volatile content in rice husk may increase the $\mathrm{CO}$ emission. The values of $\mathrm{CO}$ emission varies between $0.012 \%$ and $0.38 \%$. The effect of excess air ratio (EA) on $\mathrm{CO}$ emissions from co-firing is described in Fig. 10b. This figure shows that increasing EA leads to decreasing $\mathrm{CO}$ emissions. This is may be attributed to the increase of available $\mathrm{O}_{2}$ for the combustion process. It is worth to note that the lowest $\mathrm{CO}$ emissions (between $0.012 \%$ and $0.05 \%$ ) are recorded at the coal share of $75 \%$.

Figure 11a illustrates the impact of coal share on the NOx emissions at $\mathrm{EA}=1.85$ and $\mathrm{SAR}=50 \%$. As shown in this figure, the NOx emission increases with increasing coal share. The $\mathrm{NO}_{\mathrm{x}}$ emission varies from $100 \mathrm{ppm}$ to $520 \mathrm{ppm}$. The effect 
of EA on NOx emission is demonstrated in Fig. 11b. This figure shows that $\mathrm{NO}_{\mathrm{x}}$ emission increases with increasing EA. The increase tendency seems more clear when coal share increases. The $\mathrm{NO}_{\mathrm{x}}$ emission varies between $224 \mathrm{ppm}$ and $520 \mathrm{ppm}$. From Figs. $(10,11)$, It is noticed that $\mathrm{NO}_{\mathrm{x}}$ emissions have converse trend comparing to $\mathrm{CO}$ emissions. This is expected to be due to the catalytic reduction effect of $\mathrm{CO}$ on $\mathrm{NO}_{\mathrm{x}}$ in the flue gas. The $\mathrm{CO}$ reduces $\mathrm{NO}$ to elemental nitrogen via the following mechanism [12].

$$
2 \mathrm{CO}+2 \mathrm{NO} \rightarrow 2 \mathrm{CO}_{2}+\mathrm{N}_{2}
$$

Figure 12a depicts the variation of $\mathrm{SO}_{2}$ emission with coal share percentage at $\mathrm{EA}=1.85$ and $\mathrm{SAR}=50 \%$. As expected increasing coal share results in increasing $\mathrm{SO}_{2}$ emissions due to the higher sulfur content of coal than rice husk. The highest $\mathrm{SO}_{2}$ emission is $510 \mathrm{ppm}$ at coal share of $75 \%$. The effect of EA on $\mathrm{SO}_{2}$ emission is described in Fig. 12b. It is observed that the $\mathrm{SO}_{2}$ emission increases with increasing EA and in turn increasing $\mathrm{O}_{2}$ available for oxidizing the sulfur.

The effect of coal share on $\mathrm{O}_{2}$ concentration at $\mathrm{EA}=1.85$ and $\mathrm{SAR}=50 \%$ is shown in Fig. 13a. It can be seen that the $\mathrm{O}_{2}$ concentration decreases slightly with increasing coal share in mixture. This may be due to the higher theoretical air to fuel ratio of coal combustion (9.37 $\left.\mathrm{kg}_{\text {air }} / \mathrm{kg}_{\text {fuel }}\right)$ than rice husk combustion $\left(5.3 \mathrm{~kg}\right.$ air $\left./ \mathrm{kg}_{\text {fuel }}\right)$. Consequently the rate of combustion air required (at constant EA of 1.85) decreases when coal share increases.

The impacts of EA on $\mathrm{O}_{2}$ concentration are introduced in Fig. 13b. It is observed that, as expected, increasing EA results in increasing $\mathrm{O}_{2}$ concentration.

Figure 14a displays the variation of $\mathrm{CO}_{2}$ concentration with coal share percentage. It can be observed that increasing coal share leads to increasing the $\mathrm{CO}_{2}$ concentration because of increasing burning rate of carbon. This may be referred to the important role of circulation system in burning coal particles efficiently. The effect of EA on $\mathrm{CO}_{2}$ concentration is shown in Fig. 14b. This figure indicates that, the $\mathrm{CO}_{2}$ concentration increases with increasing EA which supports the complete combustion.

\section{CONCLUSIONS}

In the present work the effects of excess air ratio and coal share on rice husk combustion has been investigated. Several conclusions have been derived from the obtained results. The excess air ratio varied from 1.1 to 1.85 in rice husk combustion. It was found that with increasing the excess air ratio, the bed temperature and heat flux decrease, the $\mathrm{CO}$ emission in flue gas increases and $\mathrm{NO}_{\mathrm{x}}$ emission in flue gas slightly decreases. The temperature ranged between $850^{\circ} \mathrm{C}$ to $960^{\circ} \mathrm{C}$. The heat flux ranged between 40.27 and $85.23 \mathrm{~kW} / \mathrm{m}^{2}$. The condition of $\mathrm{EA}=1.1$ and $\mathrm{SAR}=50 \%$ satisfies the best conditions for lowest $\mathrm{CO}$ emission of $0.12 \%$ and highest combustion efficiency of $98 \%$.

The experiments of co-combustion of rice husk and coal were carried out at mixing ratios of $25 \%, 50 \%$, and $75 \%$ of thermal load with different excess air ratios. It was observed that increasing EA leads to decrease $\mathrm{CO}$ emissions and increase $\mathrm{NO}_{\mathrm{x}}$ emissions from co-combustion. Increasing coal share increases the temperature, heat flux, $\mathrm{CO}_{2}$ concentrations, $\mathrm{NO}_{\mathrm{x}}$ emissions, $\mathrm{SO}_{2}$ emissions while decreases $\mathrm{CO}$ 
emissions. The lowest $\mathrm{CO}$ emission of $0.012 \%$ is exhibited at $\mathrm{EA}=1.85$ (the maximum tested value) and $\mathrm{SAR}=50 \%$.

Finally It can be concluded that the co-combustion of rice husk and Sinai coal may be preferable for more efficient combustion especially when a method for sulfur capture is considered.

\section{REFERENCES}

[1] J Han, H Kim, W Minami, T Shimizu, G Wang, "The effect of the particle size of alumina sand on the combustion and emission behaviour of cedar pellets in a fluidized bed combustor", Bioresource Technology 99, pp.3782-3786, 2008.

[2] L Armesto, A Bahillo, K Veijonen, J Otero," Combustion behaviour of rice husk in a bubbling fluidized bed". Biomass and Bioenergy 23, pp. 171-179, 2002.

[3] M Fang, L Yang, G Chen, Z Shi, Z Luo, K Cen, "Experimental study on rice husk combustion in a circulating fluidized bed", Fuel Processing Technology 85, pp 1273-1282, 2004.

[4] F Santos L Goldstein, "Experimental aspects of biomass fuels in a bubbling fluidized bed combustor", Chemical Engineering and Processing 47,pp.15411549, 2008.

[5] S Eiamsa-ard, Y Kaewkohkiat, W Lelaphatikul, C Thianpong, P Promvonge, "Experimental investigation of combustion characteristics in a multi-staging vortex combustor firing rice husk".International Communications in Heat and Mass Transfer 35, pp.139-148, 2008.

[6] M Rozainee, S Ngo, A Salema, K Tan, M Ariffin, Z Zainura, " Effect of fluidising velocity on the combustion of rice husk in a bench-scale fluidised bed combustor for the production of amorphous rice husk ash"Bioresource Technology 99, pp.703-713, 2008.

[7] V Kuprianova, K Janvijitsakul, W Permchart, "Co-firing of sugar cane bagasse with rice husk in a conical fluidized-bed combustor"Fuel 85, pp.434-442, 2006.

[8] P. Sathitruangsak, T. Madhiyanon, S. Soponronnarit, "Rice husk co-firing with coal in a short-combustion-chamber fluidized-bed combustor (SFBC) "Fuel 88, pp.1394-1402, 2009.

[9] O Abd-El-Wahhab, A El-Nemr, A El-Sikaily, A Khaled, "Use of rice husk for adsorption of direct dyes from aqueous solution: A case study of direct F. scarlet", Egyptian journal of aquatic research 31, pp.1110-0354, 2005.

[10] M Youssef, S Wahid, M Hasanien, A Askalany, " Experimental study on Egyptian biomass combustion in circulating fluidized bed", Applied Energy,86, pp 2644-2650, 2009.

[11] M Youssef, S Wahid, M Abd-El-Wahhab, "Combustion characteristics of Sinai coal and biomass in a circulating fluidized bed", Proceeding of 32nd power plants technology conference, Dresden, Germany, pp 41-51, October 2000.

[12] F Okasha, S El-Emam, G Zaatar, "Fluidized bed combustion of an agriculture waste case study: combustion of rice straw", Mansoura Engineering Journal, (MEJ), Vol. 30, No 2, June 2005. 


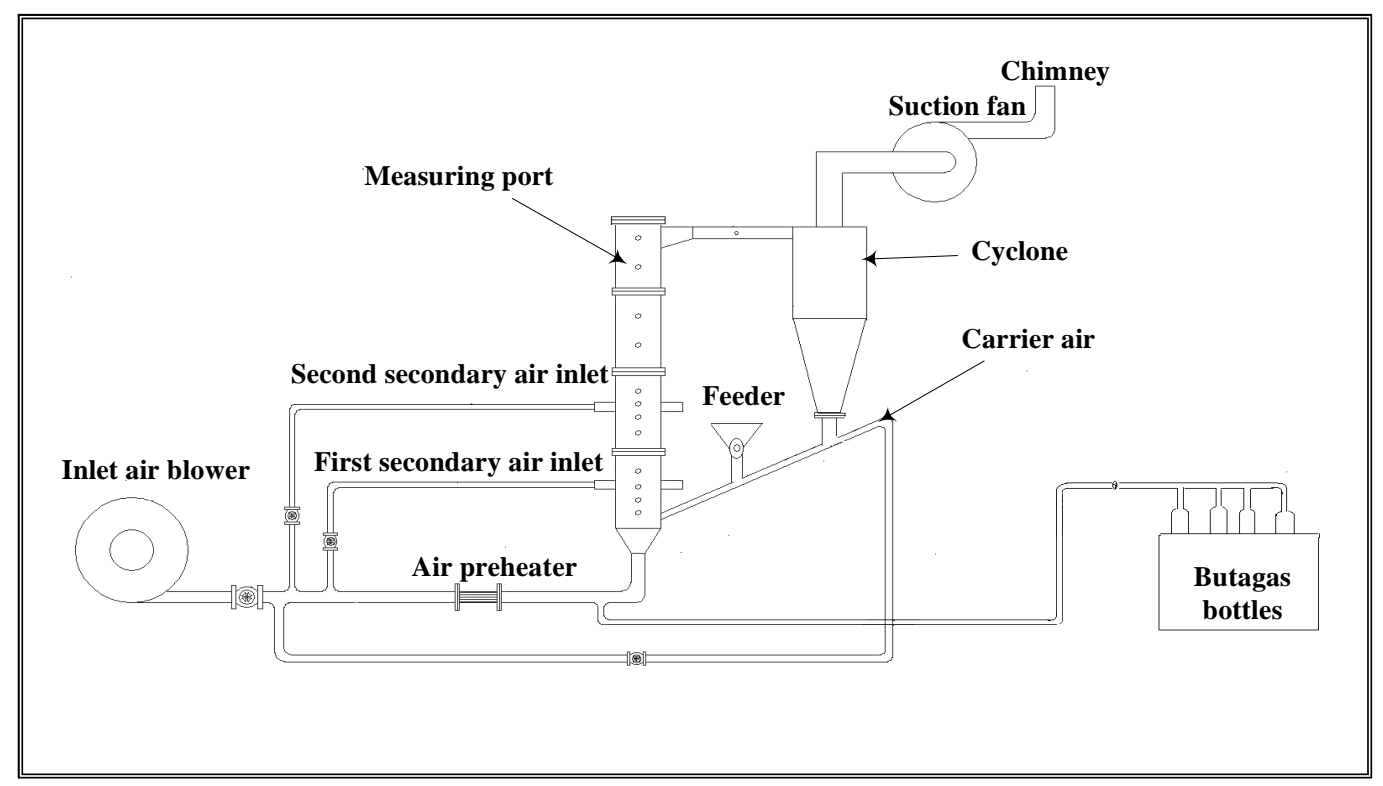

Fig. 1 Schematic diagram of circulated fluidized bed.

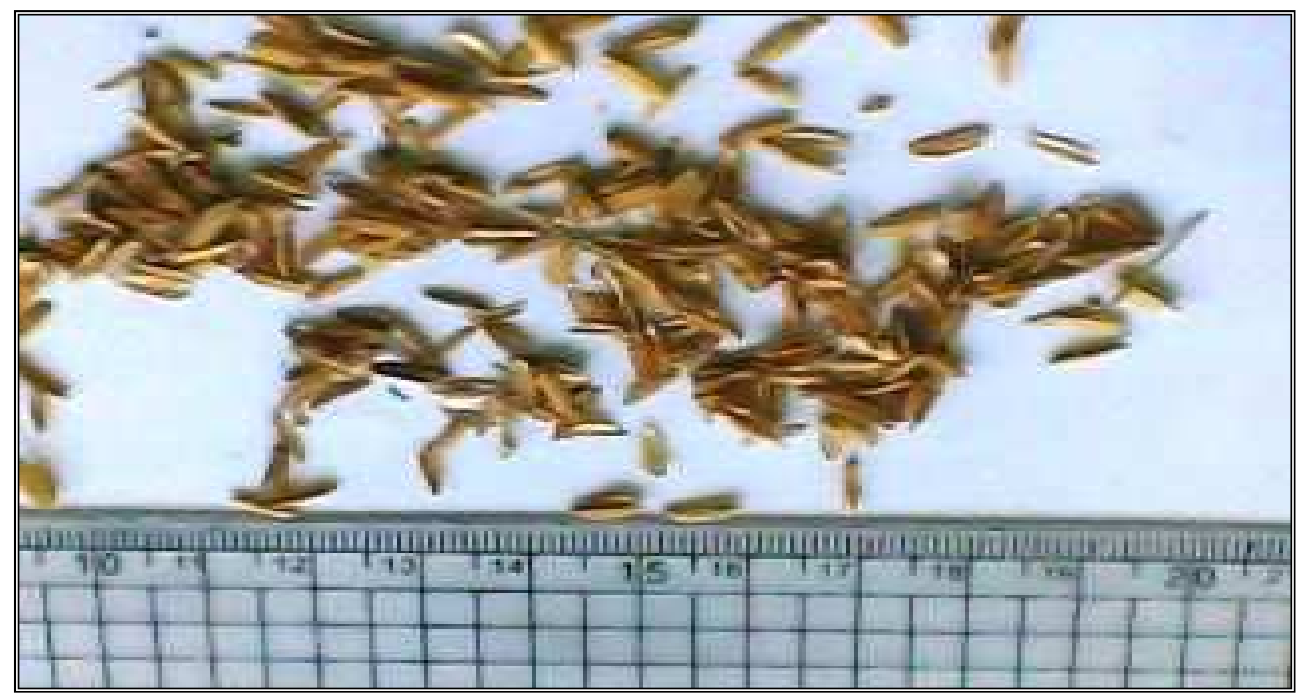

Fig. 2 Photograph of rice husk. 


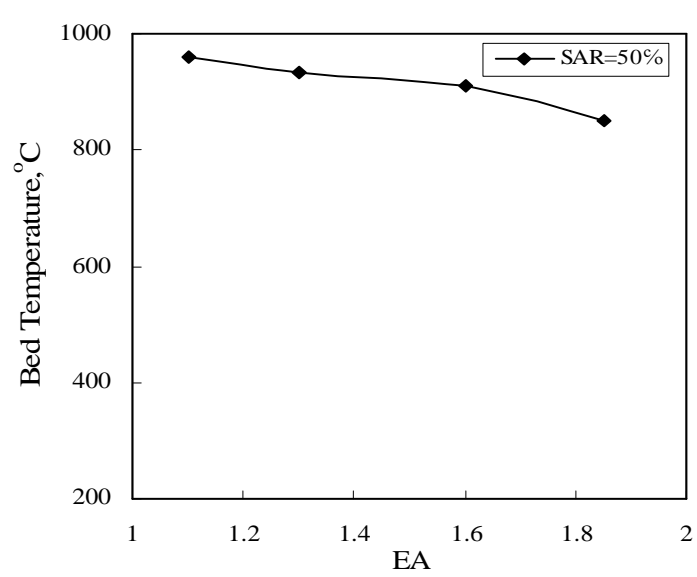

Fig. 3 Effect of excess air on bed temperature at $0.1 \mathrm{~m}$ height above air distributor for rice husk combustion.

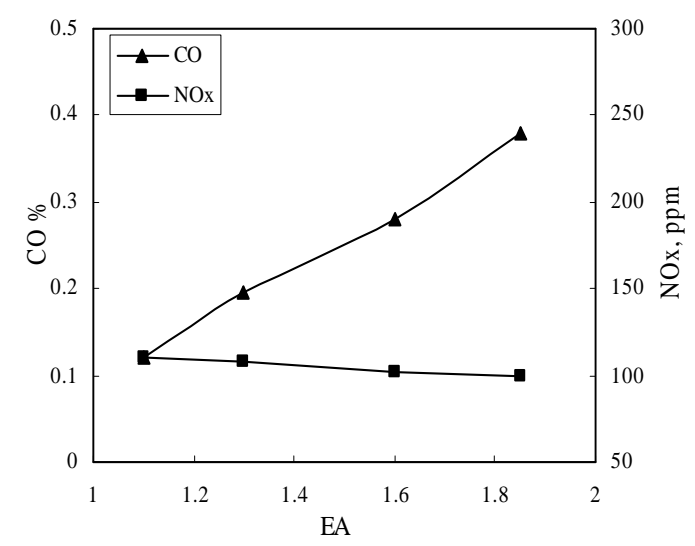

Fig. 5 Effect of excess air on $\mathrm{CO}$ and $\mathrm{NO}_{\mathrm{x}}$ emissions for rice husk combustion.

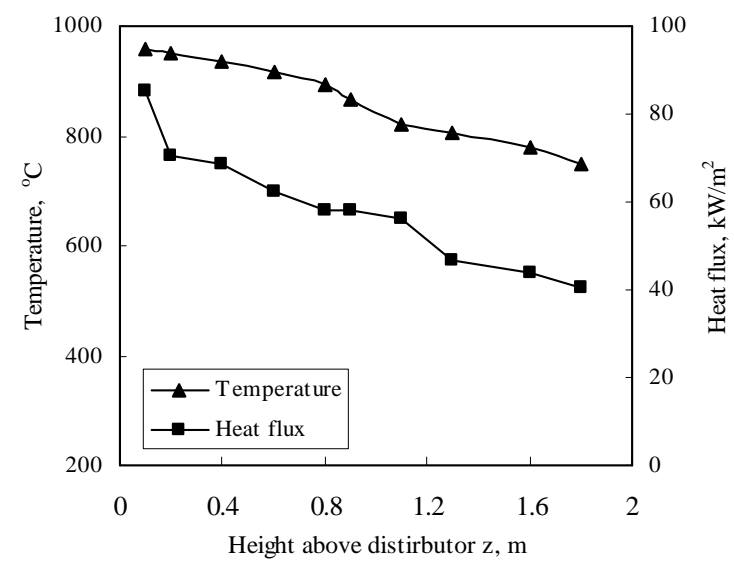

Fig. 4 Temperature and heat flux distribution along the combustion chamber for rice husk combustion.

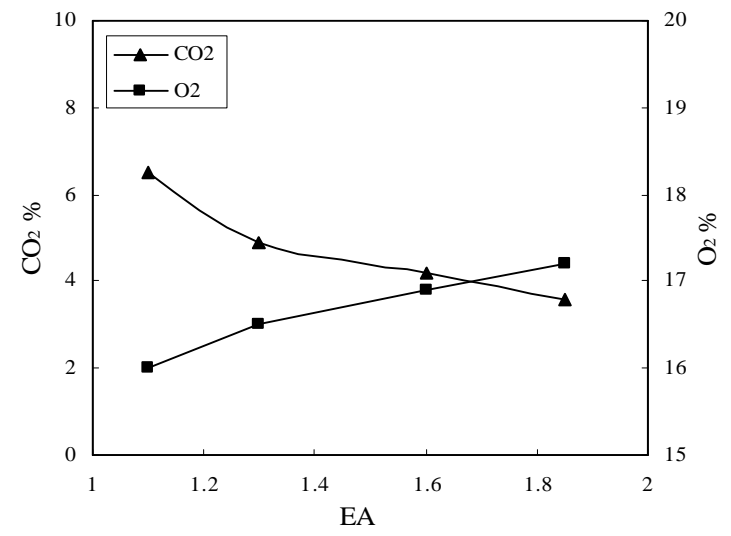

Fig. 6 Effect of excess air on $\mathrm{CO}_{2}$ and $\mathrm{O}_{2}$ concentrations for rice husk combustion.

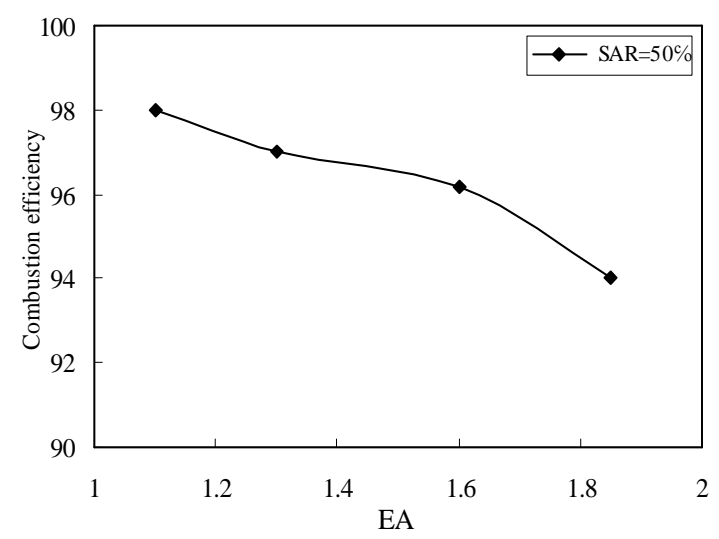

Fig. 7 Effect of excess air on combustion efficiency of rice husk 


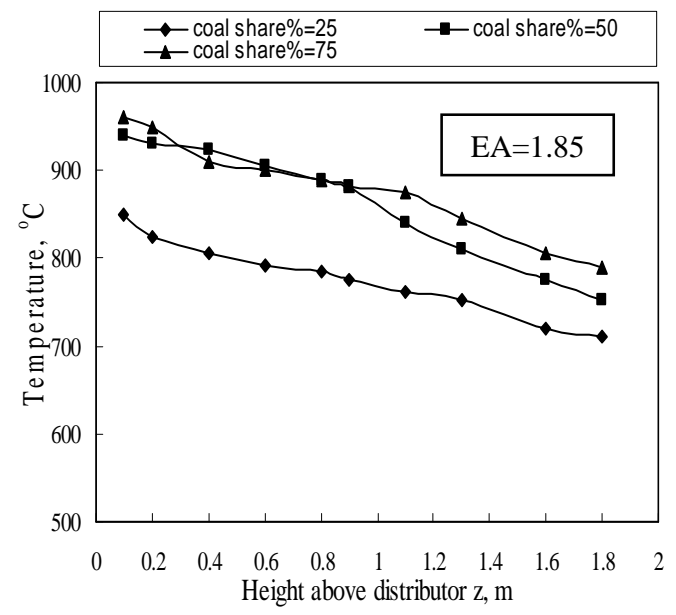

Fig. 8 Temperature distribution of cocombustion of rice husk and Sinai coal.

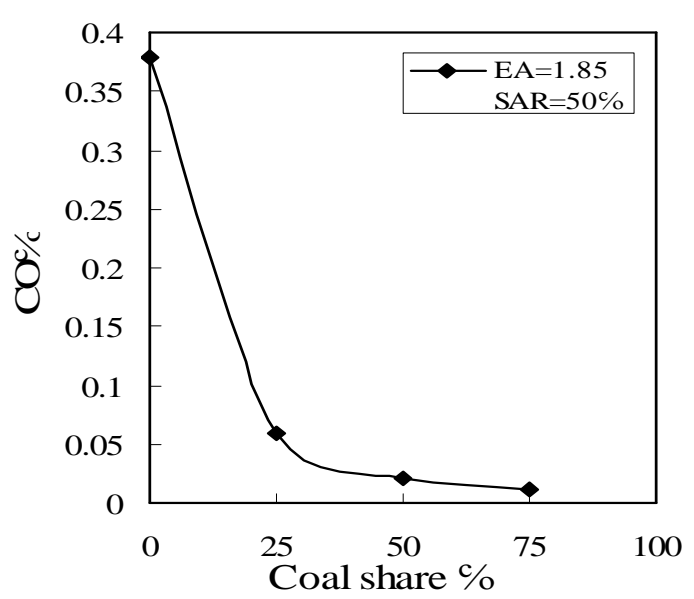

(a)

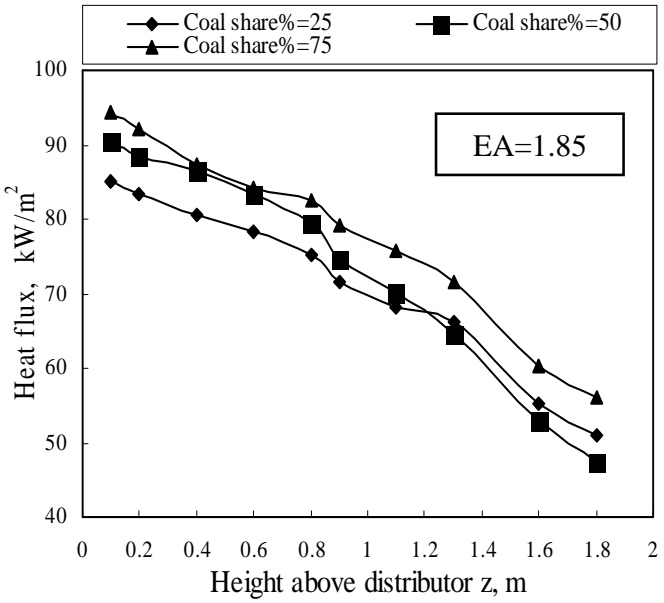

Fig. 9 Heat flux distribution of co-combustion of rice husk and Sinai coal.

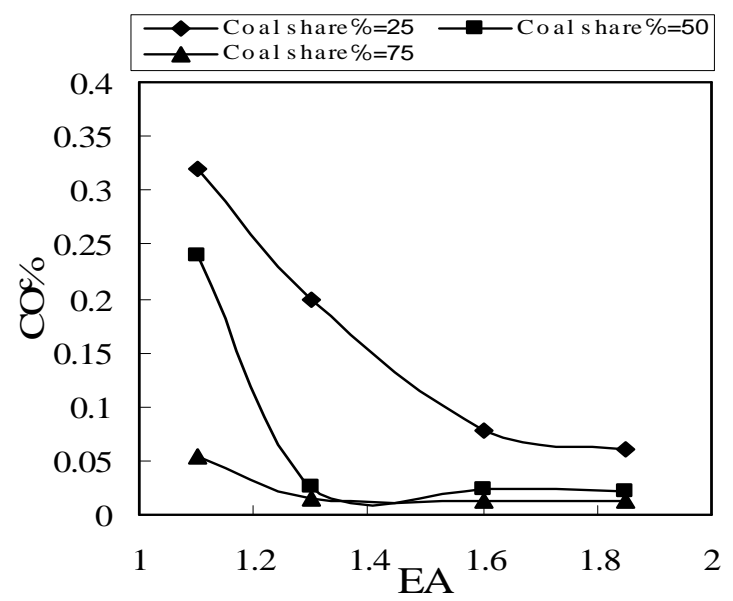

(b)

Fig. 10 Effect of coal share (a) and excess air (b) on CO emission from co-combustion of rice husk and Sinai coal 


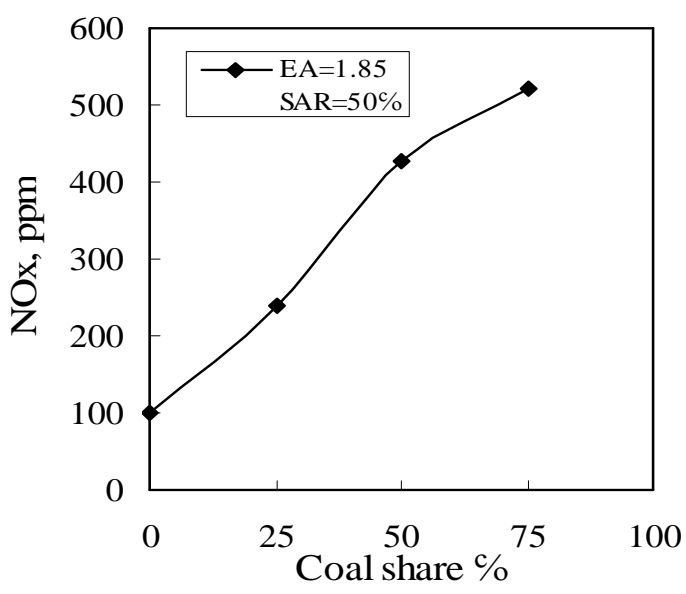

(a)

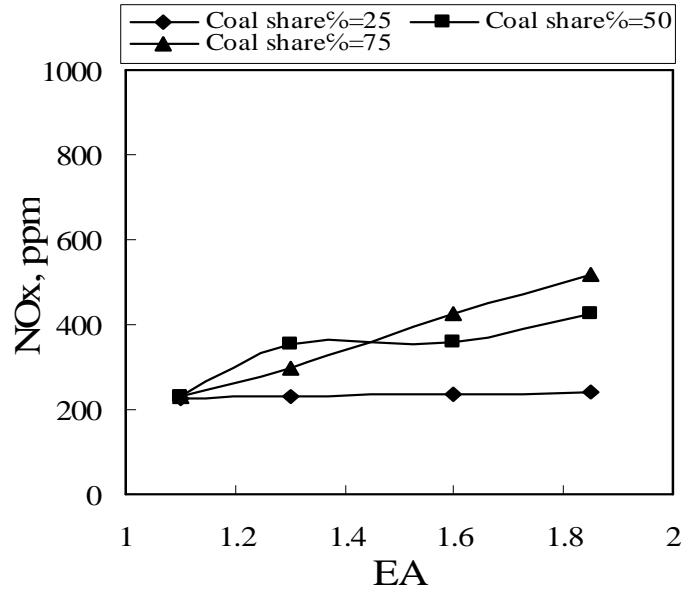

(b)

Fig. 11 Effect of coal share (a) and excess air (b) on NOx emission from cocombustion of rice husk and Sinai coal.

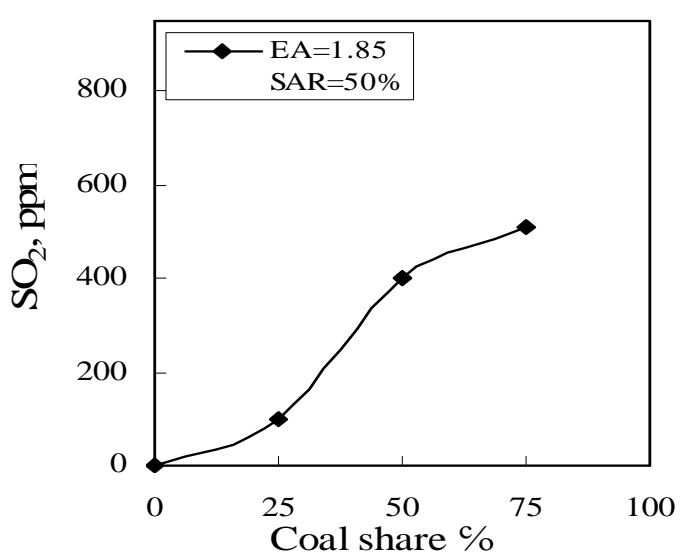

(a)

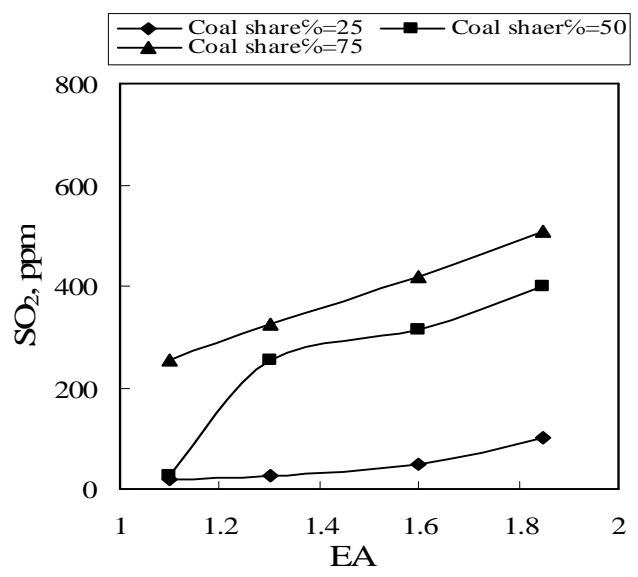

(b)

Fig. 12 Effect of coal share (a) and excess air (b) on SO2 emission from co-combustion of rice husk and Sinai coal. 


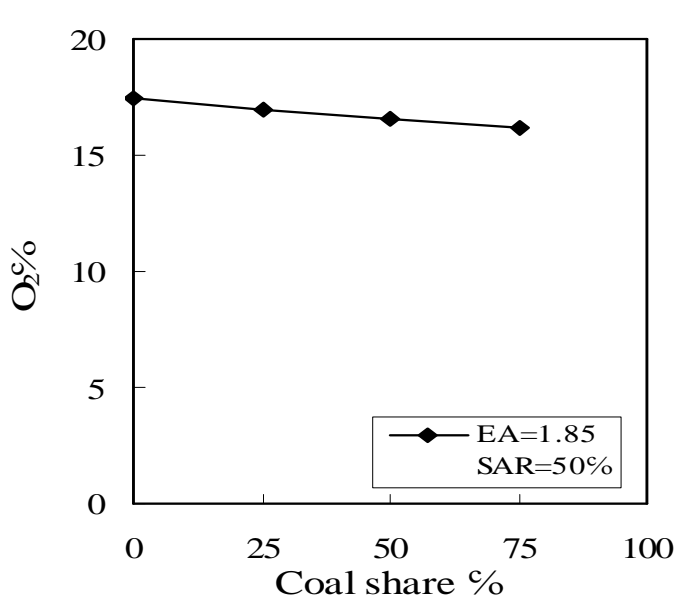

(a)

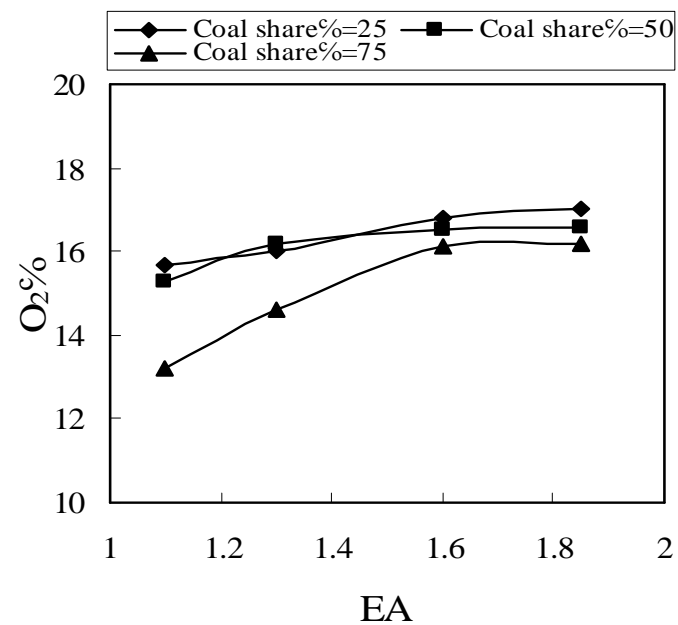

(b)

Fig. 13 Effect of coal share (a) and excess air (b) on O2 concentration from cocombustion of rice husk and Sinai coal.

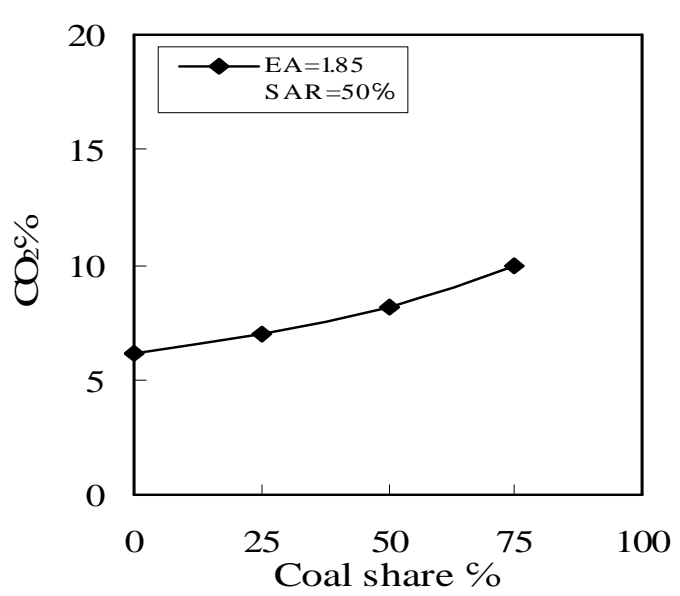

(a)

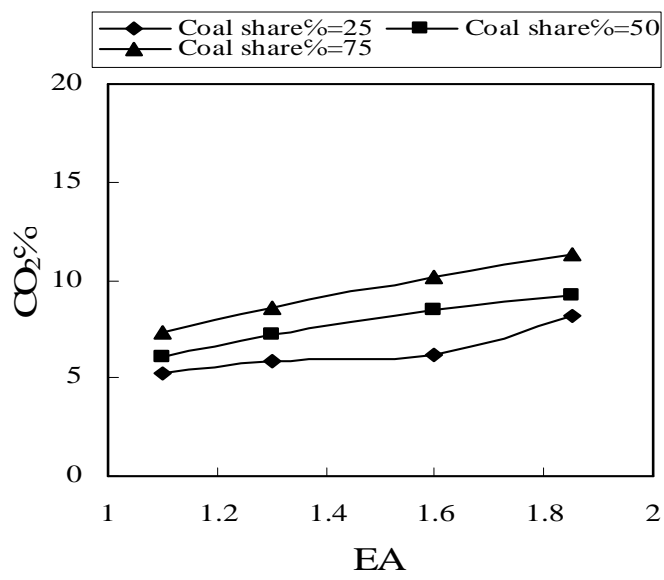

(b)

Fig. 14 Effect of coal share (a) and excess air (b) on $\mathrm{CO}_{2}$ concentration from cocombustion of rice husk and Sinai coal. 


\section{الاحترلق المشترك لقش الأرز مع فحم سيناء في المه المتميع الدوار}

يعتبر قش الأرز أحد المخلفات الزراعية الأكثر أهمية في مصر و تقدم الدراسة الحالية بحث عملي

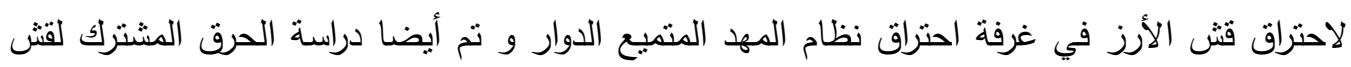

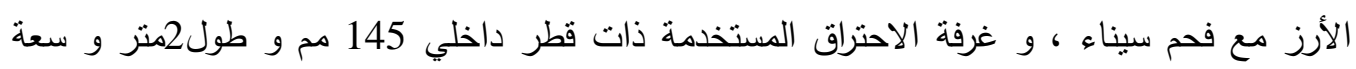

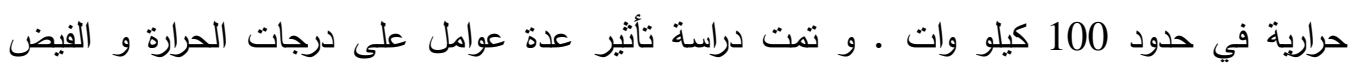

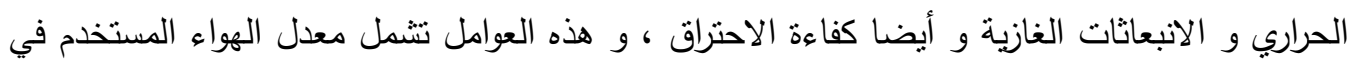
الاحتراق و الذي يزيد عن الكمية المطلوبة نظريا بنسب مختلفة و نسبة معدل الهواء الثانوي إلى معدل

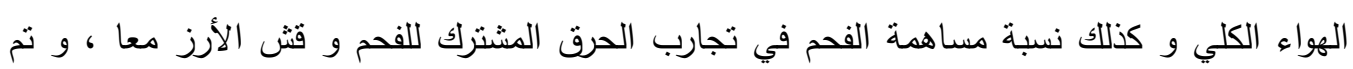
حساب كفاءة الاحتراق على أساس الفاقد الحراري بسبب الاحتراق الغير كامل و المتمثل في أول أكسيد

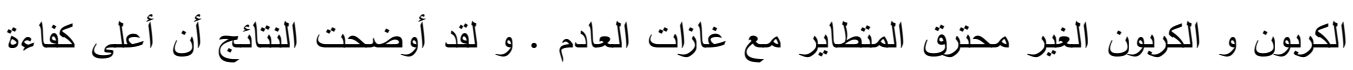

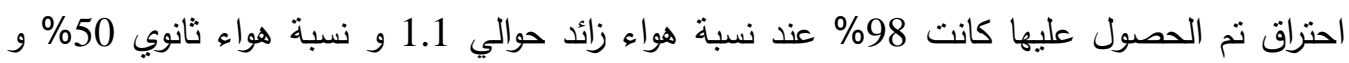

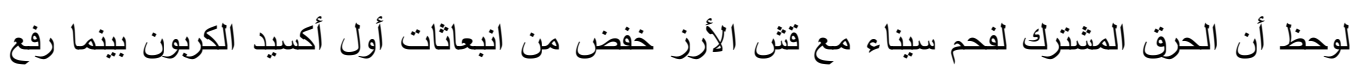

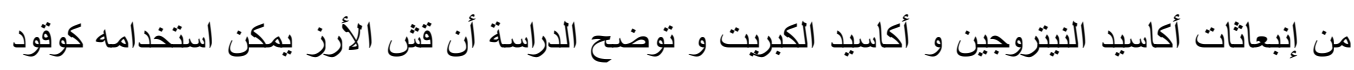

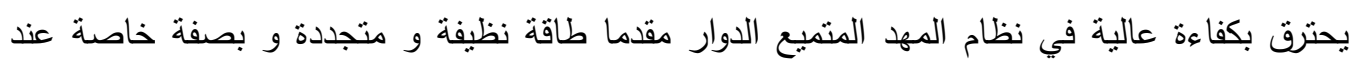
استخدام تقنية الحرق المشترك لقش الأرز مع فحم سيناء بشرط اعتماد وسيلة للتخلص من مشكلة المحتوى العالي للكبريت في فحم سيناء . 